\title{
Analisis Kesulitan Belajar Mahasiswa dalam Perkuliahan Konsep Dasar IPA Fisika Secara Daring di Masa Pandemi Covid-19
}

\author{
Puji Winarti \\ Universitas Darul Ulum Islamic Centre Sudirman GUPPI (UNDARIS) \\ pujiwinartirulian@gmail.com
}

\begin{abstract}
Abstrak
Penelitian ini bertujuan untuk mengidentifikasi kesulitan belajar mahasiswa PGSD UNDARIS dalam perkuliahan konsep dasar IPA Fisika secara daring, faktor yang mempengaruhi kesulitan belajar serta upaya yang dilakukan untuk mengatasi kesulitan belajar tersebut. Subjek penelitian adalah 16 mahasiswa PGSD UNDARIS semester genap tahun akademik 2019/2020. Metode penelitian yang digunakan adalah deskriptif kualitatif. Hasil penelitian pada tahap identifikasi kesulitan belajar mahasiswa menunjukkan bahwa rata-rata kesulitan belajar mahasiswa untuk seluruh indikator capaian adalah sebesar 60,90 $\%$. Jika di lihat dari karakteristik indikator capaian yang mahasiswa memiliki tingkat kesulitan dengan prosentasi tinggi adalah capaian indikator yang membutuhkan percobaan/ pengalaman langsung dalam proses pembelajaran. Kemudian faktor-faktor yang menyebabkan kesulitan belajar konsep dasar IPA Fisika yang dialami mahasiswa PGSD Undaris adalah faktor internal berupa faktor motivasi dari dalam diri mahasiswa serta faktor eksternal yaitu suasana rumah yang kurang mendukung, faktor ekonomi keluarga, faktor penyajian perkuliahan oleh dosen,faktor ketersediaan sarana dan prasarana penunjang serta karakteristik materi perkuliahan. Selanjutnya upaya dosen untuk mengatasi kesulitan mahasiswa adalah membangkitkan motivasi mahasiswa dengan penyajian perkuliahan yang dinilai menarik dan mengganti bahan dan alat praktikum dengan alat dan bahan yang mudah ditemui di lingkungan sekitar mahasiswa.
\end{abstract}

Kata Kunci: Kesulitan belajar, konsep dasar IPA Fisika, perkuliahan daring

\section{Analysis of Students Learning Difficulties in Education of Basic Physics Concepts Online in The Pandemic Covid-19}

\author{
Puji Winarti \\ Universitas Darul Ulum Islamic Centre Sudirman GUPPI (UNDARIS) \\ pujiwinartirulian@gmail.com
}

\begin{abstract}
This aims of the research was to identify learning difficulties of PGSD UNDARIS students in lecturing basic science concepts of Physics online, factors that affect learning difficulties and the efforts made to overcome these learning difficulties. The research subjects were 16 PGSD UNDARIS students in the even semester of the 2019/2020 academic year. The research method is a qualitative descriptive. The results of the study at the identification stage of student learning difficulties showthat the average student learning difficulties for all achievement indicators amounted to 60.90\%. If viewed from the characteristics of the achievement indicators that students have a high percentage of difficulty, it is the achievement indicators that require direct experiment / experience in the learning process. Then the factors that cause difficulties in learning the basic concepts of Natural Science in Physics experienced by PGSD Undaris students are internal factors in the form of motivational factors from within students and external factors, namely the unsupportive home atmosphere, family economic factors, lecture presentation factors by lecturers, the availability of facilities. and supporting infrastructure and characteristics of lecture materials.
\end{abstract}

Keyword: Learning difficulties, basic science concepts course Physics, online learning 


\section{PENDAHULUAN}

Pandemi corona virus and deseases (COVID) sejak akhir tahun 2019 telah banyak merubah tatanan dunia dalam berbagai sektor. Hampir seluruh Negara di dunia terdampak virus korona, termasuk Negara Indonesia. Penyebaran dan penularan virus yang sangat cepat membuat pemerintah Indonesia harus membuat banyak kebijakan untuk memutus rantai penularan. Salah satu kebijakan yang di ambil oleh pemerintah Indonesia dalam sektor pendidikan adalah menutup sekolah dan kampus serta menerapkan system belajar daeri rumah secara dalam jaringan (daring).

Kebijakan belajar dari rumah yang diambil oleh pemerintah tersebut, menuntut guru dan dosen harus melakukan penyesuaian proses pembelajaran dengan cepat. Pendidik harus menyesuaikan proses pembelajaran yang biasanya dilakukan dengan tatap muka diganti menjadi pembelajaran secara daring. Penyesuaikan ini harus dilakukan oleh seluruh jenjang pendidikan dari pendidikan anak usia dini sampai tingkat universitas tanpa pengecualian.

Penyesuaian yang harus dilakukan secara tiba-tiba dan langsung harus diterapkan tentunya membuat pendidik harus mencoba-coba metode maupun alat bantu untuk menyelenggarakan pembelajaran secara daring. Begitu juga dengan tingkat universitas, dosen harus berinovasi dengan cepat menyelenggarakan proses perkuliahan daring agar kualitas perkuliahan tidak berbeda dengan yang diselenggarakan secara luar jaringan (luring). Dalam proses ini, dosen tentu mencoba satu metode ke metode lain yang dirasa paling cocok untuk menunjang proses pembelajaran secara daring.

Begitu juga dengan proses perkuliahan yang diselenggarakan di program studi pendidikan guru sekolah dasar (PGSD), Fakultas keguruan dan ilmu pendidikan (FKIP), Universitas Darul Ulum Islamic Centre Sudirman GUPPI (UNDARIS). Dosen tentu juga memulai perkuliahan secara daring dengan mencoba menggunakan metode dan alat bantu yang dirasa sesuai dengan materi yang diajarkan, dengan harapan agar kualitas perkuliahan tidak menurun jika dibandingkan dengan perkuliahan secara luring. Akan tetapi, dalam perjalanan proses perkuliahan, dosen tentu mendapati kesulitan-kesulitan sebagai tantangan utuk dihadapi dan dicarikan solusi secepatnya.

Beberapa penelitian yang telah dilakukan oleh peneliti sebelumnya juga menemukan kesulitan-kesulitan yang dihadapi selama proses perkuliahan secara daring. Diantaranya penelitian yang dilakukan oleh (Firman dan Hermansyah, 2020), (Wijayanti, 2012) dan (Darmawan, 2019) yang menemukan beberapa kesulitan dalam pembelajaran secara daring yang dapat dikelompokkan kedalam 3 (tiga) jenis 
kesulitan yang bersifat teknis, kesulitan adaptasi dan ketidaksiapan pengajar.

Kesulitan tersebut di atas di alami oleh hampir di seluruh mata kuliah meskipun dengan permalahan yang berbeda-beda, termasuk dalam perkuliahan konsep dasar IPA Fisika. Mata kuliah konsep dasar IPA fisika adalah mata kuliah yang disajikan dengan tujuan untuk membekali pengetahuan IPA dasar mahasiswa mengenai gejala-gejala fisika seperti getaran dan bunyi, gaya dan energi dan sebagainya.

Ilmu pengetahuan alam (IPA) termasuk fisika merupakan suatu ilmu pengetahuan yang mempelajari gejala alam. Oleh karena itu, untuk mempelajari fisika muncul adanya aktivitas dalam bentuk pengamatan atau eksperimen. Berdasarkan Kamus Besar Bahasa Indonesia, fisika adalah ilmu tentang zat dan energi (seperti panas, cahaya, dan bunyi). Ada beberapa fisikawan mendefinisikan fisika sebagai ilmu pengetahuan yang tujuannya mempelajari bagian dari alam dan interaksi yang terjadi diantara bagian tersebut termasuk menerangkan sifat-sifatnya dan juga gejala lainnya yang dapat diamati.

Kesulitan-kesulitan proses perkuliahan konsep dasar IPA fisika secara daring tentunya tidak hanya dihadapi oleh dosen, tetapi juga oleh mahasiswa. Mahasiswa juga mengalami kesulitan belajar akibat sistem perkuliahan yang berubah secara cepat. Selain itu karakteristik mata kuliah konsep dasar IPA fisika yang mengharuskan adanya aktivitas dalam bentuk pengamatan dan eksperimen menjadi kendala tersendiri pada mahasiswa.

Definisi kesulitan belajar menurut The United States Office of Education (USOE) yang dikutip dalam (Mulyono, 2003)adalah suatu gangguan dalam satu atau lebih dari proses psikologis dasar yang mencakup pemahaman dan penggunaan bahasa ajaran atau tulisan.Sedangkan menurut Djamarah dalam (Haqiqi, 2018) kesulitan belajar merupakan suatu keadaaan di mana siswa tidak dapat belajar sebagaimana mestinya yang disebabkan oleh hambatan atau gangguan tertentu dalam proses pembelajaran sehingga siswa tidak dapat mencapai hasil belajar yang diharapkan. Sedangkan menurut Hamalik dalam (Wijayanti, 2012) menjelaskan bahwa yang dimaksud dengan kesulitan belajar adalah hal-hal yang bisa menyebabkan kegalalan ataupun gangguan dalam proses belajar siswa. Berdasarkan definisi di atas maka penulis dapat menyilpulkan bahwa kesulitan belajar adalah adanya gangguan ataupun kendala yang dihadapi oleh pembelajar dalam proses belajar sehingga menyebabkan ketidak tercapaian indikator keberhasilan belajar. Kesulitan belajar dapat di alami oleh semua pembelajar baik formal maupun non formal, dari jenjang pendidikan terendah sampai tertinggi dimungkinkan mengalami kesulitan belajar.

Kesulitan belajar tidak hanya disebabkan karena masalah rendahnya 
intelegensi saja. Telah banyak penelitian yang membuktikan bahwa penyebab kesulitan belajar bukan hanya masalah intelegensia, akan tetapi dipengaruhi oleh beberapa faktor. Kesulitan belajar pada siswa dapat disebabkan oleh beberapa faktor. Menurut Aunurrahman, Hakim dan Kartono dalam (Ariyati \& Nurdini, 2013) ada dua faktor penyebab kesulitan belajar pada siswa, yaitu faktor internal dan eksternal. Faktor internal meliputi minat, perhatian, motivasi dan kebiasaan belajar. Sedangkan faktor eksternal meliputi metode pembelajaran, media pembelajaran dan sumber belajar. Sementara itu menurut (Darmawan, 2019) faktor penyebab kesulitan belajar juga dipengaruhi oleh faktor internal dan eksternal. Faktor internal meliputi faktor kognitif, afektif dan psikomotorik. Faktor eksternal meliputi lingkungan sekolah, lingkungan keluarga dan lingkungan masyarakat.

Menurut (Husni, 2011)beberapa faktorfaktor yang menyebabkan kesulitan belajar pada pokoknya dapat digolongkan menjadi dua faktor yaitu faktor intern dan ekstern. Faktor Intern, meliputi: faktor biologis, kesehatan, faktor psikologis, intelegensi, perhatian, minat, bakat dan emosi. Sedangkan faktor ekstern yang meliputi: lingkungan, faktor suasana rumah, faktor ekonomi keluarga, faktor lingkungan sekolah dan faktor lingkungan masyarakat. Berdasarkan beberapa literature di atas maka peneliti menggunakan beberapa di indikator yang akan dijadikan instrument untuk mengetahui faktor-faktor penyebab kesulitan belajar mahasiswa yaitu kesehatan jasmani mahasiswa dan motivasi belajar mahasiswa sebagai indikator faktor internal. Sedangkan indikatr untuk faktor eksternal adalah dukungan dan perhatian orangtua/wali, suasana rumah yang mendukung, kondisi ekonomi keluarga, cara penyajian perkuliahan oleh dosen, ketersediaan sarana dan prasarana belajar,materi perkuliahan dan faktor lingkungan masyarakat.

Menurut (Abin, 2012) beberapa gejala siswa yang bisa diidentifikasikan mengalami kesulitan belajar jika siswa mengalami kegagalan dalam pencapaian tujuan belajar. Kegagalan belajar dapat ditunjukkan dengan beberapa kondisi yaitu; (1) Dalam batas waktu tertentu yang bersangkutan tidak mencapai ukuran tingkat keberhasilan atau tingkat penguasaan materi (mastery level) minimal dalam pelajaran tertentu yang telah ditetapkan oleh guru (criterion reference), (2) Tidak dapat mengerjakan atau mencapai prestasi semestinya, dilihat berdasarkan ukuran tingkat kemampuan, bakat, atau kecerdasan yang dimilikinya. Siswa ini dapat digolongkan ke dalam under achiever, (3) Tidak berhasil tingkat penguasaan materi (mastery level) yang diperlukan sebagai prasyarat bagi kelanjutan tingkat pelajaran berikutnya. Siswa ini dapat digolongkan ke dalam slow learner atau belum matang (immature), sehingga harus menjadi pengulang (repeater). 
Kesulitan mahasiswa dalam mempelajari materi dalam konsep dasar IPA fisika juga dipengaruhi oleh karakteristik materi konsep dasar IPA fisika. Menurut (Rusli, 2011)Ilmu fisika dasar merupakan wahana untuk menumbuhkan kemampuan berfikir yang berguna untuk memecahkan masalah dalam kehidupan sehari-hari dan membekali peserta didik pengetahuan, pemahaman dan sejumlah kemampuan yang merupakan syarat untuk memasuki jenjang pendidikan yang lebih tinggi. Lebih lanjut Trianto dalam (Abbas \& Yusuf Hidayat, 2018) menyebutkan bahwa fisika merupakan salah satu cabang dari IPA dan merupakan ilmu yang lahir dan berkembang lewat langkah-langkah ilmiah, mulai dari perumusan masalah, penyusunan hipotesis, pengujian hipotesis melalui eksperimen, penarikan kesimpulan, serta penemuan teori dan konsep.

Meskipun terkadang sebagian besar mahasiswa menganggap bahwa fisika adalah materi yang sulit akan tetapi jika di ajarkan dengan cara yang benar dan sesuai maka fisika akan menjadi mata kuliah yang menarik dan menantang keingintahuan mahasiswa. Dalam proses pembelajaran fisika, pembelajar harus memiliki konsep yang utuh dan mengerti aplikasi dari konsep tersebut. Agar pembelajar memiliki konsep yang utuh, maka harus bersentuhan ataupun mengalami langsung proses konsep yang dipelajari. Karakteristik ilmu fisika adalah pengetahuan fisis. Oleh karena itu untuk mempelajari fisika dan membentuk pengetahuan tentang fisika, diperlukan kontak langsung dengan hal yang ingin diketahui, karena fisika merupakan ilmu yang lebih banyak memerlukan pemahaman daripada hafalan.

Berkaitan dengan karakter ilmu fisika yang membutuhkan kontak langsung dengan objek yang dipelajari,maka perkuliahan yang dilakukan secara daring memiliki kesulitan tersendiri baik bagi dosen maupun bagi mahasiswa. Oleh karena itu, penelitian ini bertujuan untuk; (1) Mengidentifikasi kesulitan belajar mahasiswa PGSD UNDARIS dalam perkuliahan konsep dasar IPA Fisika secara daring di masa pandemi covid 2019, (2) Mencari faktor-faktor yang menyebabkan kesulitan belajar mahasiswa PGSD UNDARIS dalam perkuliahan konsep dasar IPA Fisika secara daring di masa pandemi covid 2019, dan (3) Melakukan upaya untuk mengatasi kesulitan belajar mahasiswa PGSD UNDARIS dalam perkuliahan konsep dasar IPA Fisika secara daring di masa pandemik covid 2019.

Oleh sebab itu peneliti perlu melakukan penelitian dengan judul "Analisis kesulitan belajar mahasiswa PGSD UNDARIS dalam perkuliahan konsep dasar IPA Fisika secara daring di masa pandemi covid 2019"

\section{METODE}

Metode penelitian yang digunakan dalam peneitian ini adalah deskriptif kualitatif. Menurut Sugiyono (2014) penelitian kualitatif adalah penelitian 
dimana peneliti ditempatkan sebagai instrument kunci, teknik pengumpulan data dilakukan secara penggabungan dan analisis data bersifat induktif. Sedangkan menurut Nana S (2012), Pendekatan kualitatif bersifat deskriptif dikarenakan penelitian deskriptif ditujukan untuk mendeskripsikan dan menggambarkan fenomena-fenomena yang ada, baik fenomena yang bersifat alamiah ataupun rekayasa manusia. Penelitian ini juga mengkaji bentuk, aktivitas, karakteristik, perubahan, hubungan, kesamaan dan perbedaannya dengan fenomena lainnya. Dasar pemikiran digunakannya metode ini adalah karena penelitian ini ingin mengetahui tentang fenomena yang ada dan dalam kondisi yang alamiah, bukan dalam kondisi terkendali, labolatoris atau eksperimen. Di samping itu, karena peneliti perlu untuk langsung terjun ke lapangan bersama objek penelitian sehingga jenis penelitian kualitatif deskripstif kiranya lebih tepat untuk digunakan.

Subjek penelitian adalah mahasiswa semester 2 program studi pendidikan guru sekolah dasar (PGSD) Fakultas Keguruan dan Ilmu Pendidikan (FKIP) UNDARIS yang berjumlah 16 mahasiswa. Subjek penelitian terdiri dari 5 laki-laki dan 11 perempuan. Penelitian dilakukan di prodi PGSD FKIP UNDARIS. Waktu penelitian di mulai 20 April 2020 sampai dengan 10 Juni 2020. Teknik pengumpulan data yang digunakan adalah teknik angket dan dokumentasi.

Adapun data yang diambil dengan teknik angket adalah data mengenai kesulitan belajar dan faktor yang mempengaruhi kesulitan belajar mahasiswa yang di berikan kepada mahasiswa dan wali mahasiswa untuk kemudian dianalisis dan digunakan sebagai data acuan untuk mencari solusi atas kesulitan yang dihadapi oleh mahasiswa. Angket yang digunakan merupakan angket terbuka dimana responden bebas menjawab semua pertanyaan yang disajikan di angket. Selain itu teknik dokumentasi digunakan untuk mengambil data hasil belajar mahasiswa selama pandemi diambil dari nilai UTS mahasiswa semester 2 PGSD UNDARIS semester genap tahun akademik 2019/2020. Pengecekan keabsahan data dengan menggunakan triangulasi sumber. Triangulasi dalam pengujian kredibilitas diartikan sebagai pengecekan data dari berbagai sumber dengan berbagai cara dan berbagai waktu (Arikunto,2010). Data angket dari mahasiswa akan dikonfrontir dengan hasil angket dari orangtua dan juga dikonfrontir dengan dokumen hasil belajar mahasiswa.

\section{HASIL DAN PEMBAHASAN}

Berdasarkan analisis data yang dilakukan penelitian ini mendapakan beberapa temuan yaitu: 
Pertama, hasil analisis kesulitan belajar mahasiswa PGSD UNDARIS dalam perkuliahan konsep dasar IPA Fisika secara daring di masa pandemi covid 2019. Berdasarkan data dokumen nilai UTS dalam mata kuliah konsep dasar IPA Fisika secara keseluruhan dari 16 mahasiswa di dapati Tabel 1. Prosentase Kesulitan belajar

\begin{tabular}{|c|c|c|c|}
\hline No & Indikator Capaian Kompetensi & $\begin{array}{l}\text { Mahasiswa yang } \\
\text { tidak mencapai nilai } \\
\text { target }\end{array}$ & Prosentase \\
\hline 1 & Mengidentifikasi besaran dan satuan dengan benar. & 4 & $25 \%$ \\
\hline 2 & $\begin{array}{l}\text { Menjelaskan sistem satuan, dimensi, dan mengkonversi } \\
\text { satuan dengan benar. }\end{array}$ & 5 & $31.25 \%$ \\
\hline 3 & $\begin{array}{l}\text { Menjelaskan penggunaan alat-alat ukur panjang, massa dan } \\
\text { waktu dengan benar. }\end{array}$ & 12 & $75 \%$ \\
\hline 4 & $\begin{array}{l}\text { Menjelaskan konsepmateri dan perubahan materidengan } \\
\text { tepat. }\end{array}$ & 5 & $31.25 \%$ \\
\hline 5 & $\begin{array}{l}\text { Menerapkan teknik pemisahan materi secara fisika dengan } \\
\text { tepat melalui percobaan. }\end{array}$ & 13 & $81 \%$ \\
\hline 6 & $\begin{array}{l}\text { Melakukan percobaan teknik pemisahan materi secara fisika } \\
\text { dengan tepat sesuai dengan prosedur. }\end{array}$ & 14 & $87.5 \%$ \\
\hline 7 & $\begin{array}{l}\text { Melakukan percobaan teknik pemisahan materi secara fisika } \\
\text { dengan tepat sesuai dengan prosedur. }\end{array}$ & 13 & $81.25 \%$ \\
\hline \multirow[t]{2}{*}{8} & $\begin{array}{l}\text { Merancang percobaan lain mengenai teknik pemisahan } \\
\text { materi secara fisika. }\end{array}$ & 12 & $75 \%$ \\
\hline & Rata-rata & & $60.90 \%$ \\
\hline
\end{tabular}

Berdasarkan data di atas maka dapat di ketahui bahwa rata-rata kesulitan belajar mahasiswa untuk seluruh indikator capaian adalah sebesar $60,90 \%$. Artinya lebih dari separuh mahasiswa mengalami kesulitan untuk menguasai 99indikator99 capaian materi pada mata kuliah konsep dasar IPA Fisika. Lebih rinci lagi maka dapat di gambarkan bahwa indikator-indikator capaian yang mahasiswa mengalami kesulitan dengan presentasi tinggi adalah menerapkan teknik pemisahan materi secara fisika dengan tepat melalui percobaan, melakukan percobaan teknik hanya 4 mahasiswa yang memenuhi nilai target perkuliahan yaitu 75. Sisanya memenuhi nilai di bawah target yang telah ditetapkan oleh dosen. Berdasarkan analisis terhadap setiap capaian kompetensi pada mata kuliah didapatkan data dengan sajian berikut : 
dimungkinkan menjadi penyebab tingginya tingkat kesulitan belajar mahasiswa dalam mata kuliah konsep dasar IPA fisika.

Perkuliahan konsep dasar IPA fisika selama indikator di prodi PGSD FKIP Undaris dilakukan dengan menggunakan beberapa platform yaitu zoom, google classroom dan video pembelajaran. Untuk protokol capaian yang sifatnya praktikum/percobaan dosen memberikan video percobaan/praktikum kemudian mahasiswa di minta untuk melakukan percobaan sendiri dirumah dengan merikukan langkah-langkah seperti yang ditampilkan di video pembelajaran.

\section{Kedua, faktor-faktor yang}

menyebabkan kesulitan belajar mahasiswa PGSD UNDARIS dalam perkuliahan konsep dasar IPA Fisika secara daring di masa pandemic covid 2019. Untuk mencari faktor-faktor penyebab kesulitan belajar mahasiswa dalam perkuliahan daring konsep dasar IPA fisika maka dilakukan pembagian angket kepada mahasiswa, wali mahasiswa dan telaah dokumen. Untuk faktor intern dari mahasiswa dalam penelitian ini diteliti dengan menggunakan 2 (dua) indikator yaitu kesehatan jasmani mahasiswa dan motivasi belajar mahasiswa. Berdasarkan angket terbuka yang diberikan kepada mahasiswa dan orang tua dapat ditarik data bahwa dari 16 (enam belas) mahasiswa hanya 2 (dua) mahasiswa yang mengalami gangguan kesehatan selama proses perkuliahan konsep dasar IPA fisika. Satu orang gangguan kesehatan karena sempat kecelakaan dan satu orang lagi karena mengalami demam dan influenza.

Berkenaan dengan sedikitnya siswa yang mengalami gangguan kesehatan jasmani ketika perkuliahan konsep dasar IPA Fisika maka dapat disimpulkan bahwa faktor kesehatan jasmani bukan menjadi faktor penyebab kesulitan belajar mahasiswa belajar konsep dasar IPA Fisika. Faktor intern yang kedua adalah motivasi belajar. Berdasarkan angket yang diberikan kepada mahasiswa pada intinya mahasiswa tertarik mengikuti perkuliahan konsep dasar IPA fisika. Akan tetapi karena perkuliahan dilakukan secara daring, mahasiswa tidak dapat beriteraksi secara langsung dengan dosen maupun dengan alat-alat yang seharusnya bisa digunakan untuk praktikum langsung maka motivasi belajarnya menjadi turun. Dari 16 siswa terdapat 12 mahasiswa yang menyatakan mengalami penurunan motivasi perkuliahan konsep dasar IPA fisika secara daring.

Begitu juga dengan angket yang diberikan kepada wali mahasiswa yang seluruhnya menyatakan bahwa anaknya rajin mengikuti perkuliahan secara daring meskipun terkadang ada yang sambil tiduran atau bahkan tertidur. Dosen juga merasakan bahwa mahasiswa kurang begitu tertarik menanggapi materi yang disampaikan. Hal ini terlihat dari sepinya respon mahasiswa dalam sesi diskusi yang diadakan secara online oleh dosen melalui google classroom. 
Menurut (Nur laili, 2019) salah satu ciri tidak adanya motivasi belajar adalah siswa tidak kritis dalam menanggapi masalah yang diberikan oleh guru. Oleh sebab itu sepi nya respon mahasiswa dapat dikatakan menggambarkan rendahnya motivasi belajar mahasiswa.

Menurunnya motivasi mahasiswa dalam perkuliahan konsep dasar IPA fisika dapat dikatakan menjadi salah satu faktor penyebab kesulitahan belajar mahasiswa dalam perkuliahan konsep dasar IPA. Motivasi yang menurun tentunya membuat semangat belajar menurun dan mengakibatkan siswa mengalami kesulitan belajar. Penelitian lain yang pernah dilakukan oleh (Dzurri,2019), (Marisa,2019),(Asmanullah et al., 2019) setidaknya memberikan gambaran kepada kita semua bahwa ternyata motivasi memiliki pengaruh yang sangat besar terhadap kesulitan belajar yang dihadapi oleh pembelajar dan cara menyelesaikan permasalaha belajar yang di hadapi. Begitu juga dengan penelitian ini, motivasi ternyata menjadi salah satu faktor penyebab kesulitan belajar mahasiswa dalam belajar konsep dasar IPA fisika.

Untuk faktor-faktor eksternal penyebab kesulitan belajar mahasiswa dalam perkuliahan konsep dasar IPA fisika diteliti dengan menggunakan 7 (tujuh) indikator yaitu dukungan dan perhatian orangtua/wali,suasana rumah yang mendukung,kondisi ekonomi keluarga, cara penyajian perkuliahan oleh dosen, ketersediaan sarana dan prasarana belajar,materi perkuliahan dan faktor lingkungan masyarakat. Untuk faktor dukungan dan perhatian orangtua, 8 mahasiswa menyatakan diberikan dukungan penuh oleh wali mahasiswa dan 5 mahasiswa menyatakan bahwa orangtua cuek dengan proses perkuliahan akan tetapi tetap memberikan waktu untuk kuliah daring.

Sementara 3 mahasiswa lainnya merasa tidak mendapatkan dukungan dari wali/orangtua karena wali/orang tua menganggap mahasiswa libur, meskipun sebenarnya perkuliahan tetap berjalan secara daring. Bentuk ketidak pedulian wali/orangtua mahasiswa dinyatakan dalam bentuk misalnya menyuruh melakukan kegiatan lain saat jam perkuliahan, tidak menjaga suasana perkuliahan dan sebagainya. Berkenanaan dengan banyaknya orangtua yang kurang memberikan dukungan kepada mahasiswa dalam perkuliahan tidak sebanding dengan banyaknya mahasiswa yang dikategorikan mengalami kesulitan belajar maka faktor perhatian dan dukungan orangtua belum cukup disimpulkan bahwa menjadi salah satu penyebab kesulitan mahasiswa dalam belajar mata kuliah konsep dasar IPA fisika.

Faktor selanjutnya adalah suasana rumah yang mendukung proses perkuliahan daring. 11 dari 16 mahasiswa menyatakan suasana rumah mereka kurang mendukung 
perkuliahan secara daring. Beberapa alas an yang disampaikan oleh mahasiswa adalah rumahnya berada pada tempat yang ramai dipinggir jalan utama, anggota keluarga banyak sehingga suasana rumah ramai atau bahkan mahasiswa ada yang tinggal rumahnya sekaligus membuka warung sehingga ramai dengan pelanggan sehingga suasana rumah kurang mendukung proses perkuliahan secara daring. Pernyataan mahasiswa ini juga didukung oleh data hasil angket dari orang tua yang menyatakan hal yang sama bahwa rumah mereka kurang mendukung proses perkuliahan secara daring.

Faktor selanjutnya adalah kondisi ekonomi keluarga. Berdasarkan angket yang diberikan mahasiswa menyatakan berada pada keluarga yang kondisi keuangannya menengah ke bawah. Bahkan ada 2 mahasiswa yang orangtuanya dirumahkan karena terkena dampak pandemi. Data yang sama juga didapatkan dari angket wali mahasiswa/orangtua mahasiswa.

Berdasarkan data yang didapatkan tersebut dapat ditemukan indikasi mengapa mahasiswa kurang bisa menyediakan sarana dan prasarana yang cukup memadai untuk perkuliahan konsep dasar IPA fisika karena kondisi ekonomi wali/orangtua mahasiswa yang berada pada kondisi ekonomi menengah ke bawah. Dengan demikian maka dapat disimpulkan bahwa kondisi ekonomi keluarga menjadi salah satu faktor penyebab kesulitan belajar konsep dasar IPA fisika karena berkaitan dengan penyediaan sarana dan prasarana perkuliahan secara daring.

Faktor selajutnya penyebab kesulitan belajar yang diteliti adalah cara penyajian perkuliahan oleh dosen. Berdasarkan angket yang diberikan kepada mahasiwa cara penyajian perkuliahan secara daring artinya perkuliahan dilakukan dengan menggunakan media baik zoom, google classroom maupun video membuat mahasiswa kesulitan memahami materi konsep dasar IPA fisika. Hal ini dikarenakan, mahasiswa tidak bisa bertanya secara langsung sebanyak ketika mahasiswa bertemu langsung dengan dosen. Selain itu tidak minimnya diskusi antar mahasiswa menyebabkan pembelajaran lebih bersifat 1 arah yaitu dosen menyampaikan materi kemudian mahasiswa mengerjakan tugas yang diberikan oleh dosen baik tugas praktikum ataupun tertulis.

Penyampaian pembelajaran yang seperti ini menyebabkan komunikasi mahasiswa dengan dosen berkurang, entah itu komunikasi dalam rangka bertanya mengenai hal yang belum dimengerti ataupun meminta penjelasan ulang dan sebagainya. 12 dari 16 mahasiswa menyatakan mereka belum puas dengan perkuliahan konsep dasar IPA fisika yang disajikan oleh dosen secara daring. Begitu juga dengan orangtua, orangtua yang perduli dengan anaknya merasa terbebani karena ikut serta membantu menyediakan alat dan bahan percobaan dirumah. Dengan demikian 
maka cara penyajian perkuliahan konsep dasar IPA secara daring dapat dikategorikan sebagai faktor penyebab kesulitan belajar mahasiswa dalam perkuliahan konsep dasar IPA Fisika.

Faktor eksternal selanjutnya yang di analisis adalah ketersediaan sarana dan prasarana belajar mahasiswa. Berdasarkan angket yang diberikan oleh mahasiswa 14 dari 16 mahasiswa tidak memiliki sarana dan prasarana serta fasilitas yang cukup memadai untuk menunjang perkuliahan konsep dasar IPA secara daring. Sebagian besar yang dimilki oleh mahasiswa adalah HP android. Sementara untuk menunjang keberhasilan indicator capaian dalam mata kuliah konsep dasar IPA secara daring adalah selain jaringan dan laptop mahasiswa harus memiliki beberapa alat untuk praktikum dirumah secara mandiri.

Hal inilah yang menjadi kesulitan tersendiri bagi mahasiswa. Karena untuk menyediakan alat-alat yang dibutuhkan mereka harus membeli dan mahasiswa merasa keberatan sehingga mahasiswa memilih hanya melihat demo praktikum yang disajikan oleh dosen melalui zoom saja. Hal inilah yang disinyalir menjadikan mahasiswa kurang menguasai aplikasi dari konsep dasar IPA fisika yang diajarkamn oleh dosen secara dalam jaringan. Selain itu masalah sinyal juga menjadi kendala tersendiri oleh mahasiswa. Karena sebagain besar mahasiswa bertempat tinggal dipegunungan didaerah bandungan dan sekitarnya yang mana sinyal tidak selancar yang diharapkan.Penelitian lain mengenai pengaruh ketersediaan sarana dan prasarana terhadap munculnya kesulitan belajar juga telah banyak dilakukan diantara oleh(Khairuzzaman, 2016),(Murniarti et al., 2016) yang menyatakan bahwa ketersediaan sarana dan prasarana belajar menjadi faktor penting penyebab munculnya kesulitan belajar.

Faktor selanjutnya adalah materi perkuliahan. Sseperti yang telah dibahas sebelumnya bahwa materi perkuliahan konsep dasar IPA fisika adalah materi perkuliahan dimana membutuhkan interaksi langsung antara pembelajar dengan objek yang dipelajari. Hal ini juga diperkuat dengan indikator capaian yang mengharuskan mahasiswa terampil mengaplikasikan konsep tertentu dalam bentuk praktikum. Oleh sebab itu, karakter materi perkuliahan menjadi salah satu faktor penyebab kesulitan belajar yang dialami mahasiswa dalam perkuliahan konsep dasar IPA Fisika.

Faktor eksternal yang terakhir adalah faktor lingkungan masyarakat. Berdasarkan agket yang diberikan oleh mahasiswa 15 dari 16 mahasiswa menyatakan bahwa mereka memiliki lingkungan masyarakat yang cukup kondusif untuk mengikuti perkuliahan secara dalam jaringan. Hanya ada 1 (satu) mahasiswa yang menyatakan berada di lingkungan yang cukup ramai karena rumahnya berada diruko dekat pasar 
dan ramai. Kadang-kadang pengunjung rumahnya kurang menghormati mahasiswa yang tengah melakukan perkuliahan daring dan malah gaduh. Akan tetapi karena hanya 1 (satu) mahasiswa yang memiliki problem ini maka faktor lingkungan masyarakat di sinyalir tidak menjadi faktor penyebab kesulitan belajar mahasiswa dalam perkuliahan konsep dasar IPA fisika.

Secara garis besar berdasarkan analisis data yang dilakukan maka faktorfaktor yang mempengaruhi kesulitan belajar mahasiswa dapat diperinci sebagai berikut: faktor internal berupa faktor motivasi dari dalam diri mahasiswa serta faktor eksternal yaitu suasana rumah yang kurang mendukung, faktor ekonomi keluarga, faktor penyajian perkuliahan oleh dosen,faktor ketersediaan sarana dan prasarana penunjang serta karakteristik materi perkuliahan.

Hasil penelitian yang ditemukan dalam penelitian ini secara garis besar turut membuktikan hasil penelitian sebelumnya yang dilakukan oleh (Firman dan Hermansyah, 2020), (Wijayanti,2012) dan (Darmawan,2019) bahwa kesulitan yang dihadapi dalam perkuliahan secara dar9ing selama pandemic covid 2019 dapat dikelompokkan ke dalam 3 hal yaitu masalah yang berkaitan dengan teknis, kesulitan adaptasi dan ketidaksiapan pengajar. Untuk hasil temuan dalam penelitian ini kesulitan dalam hal teknis ditemukan adanya beberapa mahasiswa yang tidak memiliki sarana dan prasarana yang memadai untuk perkuliahan daring serta kesulitan jaringan yang dialami oleh beberapa mahasiswa. Selain itu hasil penelitian ini juga menemukan adanya ketidaksiapan pengajar yaitu dosen belum menemukan metode dan teknik yang sesuai dalam menyelengarakan perkuliahan secara daring.

Ketiga, upaya untuk mengatasi kesulitan belajar mahasiswa PGSD UNDARIS dalam perkuliahan konsep dasar IPA Fisika secara daring di masa pandemic covid 2019. Setelah diketahui faktor-faktor penyebab kesulitan belajar mahasiswa dalam perkuliahan konsep dasar IPA maka dosen melakukan sesuatu sebagai upaya untuk mengatasi berbagai kesulitan tersebut.

Beberapa upaya yang dilakukan oleh dosen, yang pertama adalah membangkitkan motivasi mahasiswa dengan penyajian perkuliahan yang dinilai menarik. Untuk mendongkrak motivasi mahasiswa maka dosen mengubah strategi dan teknik pembelajaran yaitu dengan menggunakan video pembelajaran yang disertai kuis interaktif. Video pembelajaran ini kemudian di upload di platform edmodo. Platform edmodo di pilih karena tampilannya yang seperti facebook memungkinkan mahasiswa lebih familiar dan termotivasi untuk berinteraksi antara satu dengan yang lain. Selain itu, menurut penelitian yang dilakukan oleh (Agatha, 2020) penggunaan platform edmodo dalam pembelajaran fisika 
terbukti dapat meningkatkan hasil belajar mahasiswa.

Upaya -upaya perbaikan pengajaran oleh dosen ini dilakukan agar mahasiswa berinteraksi aktif dan benar-benar mengikuti dengan baik perkulihan yang disajikan. Memperbaiki cara pengajaran dosen adalah hal yang wajib dilakukan saat dosen menemukan gejala kesulitan belajar dari dalam diri mahasiswa. Hal ini sesuai dengan teori yang disampaikan oleh (Susanti, 2018) yang menyatakan bahwa pendidik memiliki peran kunci dalam keberhasilan proses pembelajaran.

Dalam video ini juga disediakan demo praktikum untuk memberikan gambaran langsung aplikasi konsep yang telah diajarkan sehingga mahasiswa bisa memutar berulangkali agar dapat memahami aplikasi dari konsep tersebut. Dengan langkah ini maka dosen berharap dapat mengatasi kesulitan belajar mahasiswa yang disebabkan oleh minimnya motivasi, faktor penyajian perkuliahan faktor ketersediaan sarana dan prasarana serta karakteristik materi perkuliahan konsep dasar IPA fisika secara daring.

Upaya kedua yang dilakukan oleh dosen adalah mengganti bahan dan alat praktikum dengan alat dan bahan yang mudah ditemui di lingkungan sekitar mahasiswa. Untuk mengatasi kesulitan mahasiswa dam menyediakan alat dan bahan praktikum maka dosen mengganti alat dan bahan praktikum dengan alat dan bahan yang mudah ditemui disekitar rumah mahasiswa sehingga mahasiswa tetap dapat melakukan praktikum secara mandiri untuk mengaplikasikan konsep yang dipelajari. Selain itu, pengkajian terhadap fenomena atau kebudayaan lokal dan mengkajinya dari aspek konsep fisika (etnosains) merupakan alternatif untuk bisa menenamkan konsep fisika secara efektif.

Beberapa peneliti juga telah membuktikan bahwa pendekatan etnosains dapat digunakan untuk mengefektifkan pembelajaran fisika, diantaranya adalah penelitian yang dilakukan oleh Novitasari. Peran fisika dan etnosains sangat penting dalam pembelajaran sains mengingat luasnya cakupan ilmu fisika sebagai salah satu ranah etnosains. (Novitasari et al., 2017).

Praktikum mahasiswa kemudian dipantau oleh dosen dengan memberikan petunjuk dan pertanyaan yang membimbing mahasiswa untuk membangun atau menemukan sendiri konsep yang dipelajari. Hal ini dirasa efektif untuk membantu mempermudah belajar siswa agar mengurangi kesulitan belajar yang dihadapi. Hal ini sesuai dengan temuan yang dihasilkan oleh penelitian (Wijayanti, 2012). Selain itu, jika alat dan bahan praktikum yang benar-benar tidak bisa digantikan oleh alat dan bahan lain yang mudah ditemui oleh mahasiswa maka dosen memberikan giliran kepada mahasiswa tiap 2 orang dalam satu hari untuk melakukan praktikum 
dilaboratorium kampus. Dengan demikian maka protokol kesehatan tetap dapat dijalankan dan praktikum tetap bisa dilakukan.

\section{SIMPULAN DAN SARAN}

Berdasarkan analisis yang dilakukan maka dapat disimpulkan beberapa hal yaitu; (1) Berdasarkan data dokumen nilai UTS dalam mata kuliah konsep dasar IPA Fisika secara keseluruhan dari 16 mahasiswa di dapati hanya 4 mahasiswa yang memenuhi nilai target perkuliahan yaitu 75 dan ratarata dari keseluruhan indikator capaian maka kesulitan belajar yang dialami oleh mahasiswa sebesar $60.90 \%$. Temuan ini membuktikan bahwa mahasiswa mengalami kesulitan belajar dalam perkulihaan konsep dasar IPA Fisika secara daring, (2) Faktorfaktor yang mempengaruhi kesulitan belajar mahasiswa yaitu faktor internal berupa faktor motivasi dari dalam diri mahasiswa serta faktor eksternal yaitu suasana rumah yang kurang mendukung, faktor ekonomi keluarga, faktor penyajian perkuliahan oleh dosen,faktor ketersediaan sarana dan prasarana penunjang serta karakteristik materi perkuliahan, (3) Upaya dosen untuk mengatasi kesulitan mahasiswa adalah membangkitkan motivasi mahasiswa dengan penyajian perkuliahan yang dinilai menarik dan Mengganti bahan dan alat praktikum dengan alat dan bahan yang mudah ditemui di lingkungan sekitar mahasiswa.

\section{DAFTAR PUSTAKA}

Abdurrahman, Mulyono. (2012). Anak Berkesulitan Belajar: Teori, diagnosis, dan remediasinya. Jakarta: Rineka Cipta.

Abin Syamsuddin Makmun. (2012). Psikologi Kependidikan: Perangkat Sistem Pengajaran Modul. Bandung : Remaja Rosdakarya.

Abbas, A., \& Yusuf Hidayat, M. (2018). FAKTOR-FAKTOR KESULITAN BELAJAR FISIKA PADA PESERTA DIDIK KELAS IPA SEKOLAH MENENGAH ATAS. JPF (Jurnal Pendidikan Fisika) Universitas Islam Negeri Alauddin Makassar, 6(1), 45-49. https://doi.org/10.24252/jpf.v6i1a8

Agatha, H. Maria. (2020). Penerapan E-learning dengan platform edmodo untuk meningkatkan hasil belajar mahasiswa. Jurnal Komunikasi Pendidikan. 4 (1), 1-8. http://journal.univetbantara.ac.id/index.php /komdik/article/view/442

Arikunto, S. 2010. Prosedur Penelitian. Jakarta: Rineka Cipta.

Ariyati, E., \& Nurdini, A. (2013). Deskripsi Kesulitan Belajar Dan Faktor Penyebabnya Pada Materi Fungi Di Sma Islam Bawari Pontianak Dan Upaya Perbaikannya. Jurnal Pendidikan Dan Pembelajaran Untan, 2(9).

Asmanullah, A. S., Hamdani, A., \& Indonesia, U. P. (2019). Faktor Penyebab Kesulitan Belajar Siswa Pada Mata Pelajaran Mekanika Teknik Di Smk Bidang Teknologi Dan Rekayasa Kota Bandung. Journal of Mechanical Engineering Education, 6(1), 13-22. https://doi.org/10.17509/jmee.v6i1.18236

Darmawan, D. (2019). Anak berkesulitan belajar. Journal of Chemical Information and Modeling, 53(9), 1689-1699. http://eprints.ums.ac.id/63834/4/BAB II..pdf

Firman dan Hermawan. (2020). Analisis Kesulitan Mahasiswa Pendidikan Matematika Dalam Pembelajaran Daring Pada Masa Pandemi Covid-19. Jurnal 
Pedagoria, $11 \quad$ (2), 195-201. https://journal.ummat.ac.id/index.php/paed agoria/issue/view/253

Wijayanti. (2012). EKSPLORASI KESULITAN BELAJAR SISWA PADA POKOK BAHASAN CAHAYA DAN UPAYA PENINGKATAN HASIL BELAJAR MELALUI PEMBELAJARAN INKUIRI TERBIMBING. (2012). Jurnal Pendidikan Fisika Indonesia, 6(1), 1-1. https://doi.org/10.15294/jpfi.v6i1.1093

Haqiqi, A. K. (2018). ANALISIS FAKTOR PENYEBAB KESULITAN BELAJAR IPA SISWA SMP KOTA SEMARANG. Edu Sains: Jurnal Pendidikan Sains \& Matematika, $\quad 6(1), \quad 37$. https://doi.org/10.23971/eds.v6i1.838

Husni, D. (2011). Adhd Dalam Kesulitan Belajar. 3.

Khairuzzaman, M. Q. (2016). pengaruh sarana prasarana sekolah dan motivasi belajar siswa terhadap prestasi belajar siswa pemasaran di smk negeri 1 sukoharjo tahun ajaran 2015/2016. 4(1), 64-75. https://jurnal.uns.ac.id/bise/article/view/16 956

Marisa, S. (2019). Pengaruh Motivasi dalam Pembelajaran Siswa Upaya Mengatasi Permaslahan Belajar. Jurnal Taushiah, 9(2), 20-27.

Mulyono, A. (2003). Pendidikan bagi anak berkesulitan belajar. Jakarta: Rineka CiptaMulyono, A. (2003). Pendidikan Bagi Anak Berkesulitan Belajar. Jakarta: Rineka Cipta, 33339. https://doi.org/10.1016/j.jcjo.2015.03.008, 33339.

https://doi.org/10.1016/j.jcjo.2015.03.008

Murniarti, D., Purwaningsih, E., \& Buwono, S. (2016). Pengaruh Sarana Dan Prasarana Terhadap Hasil Belajar Siswa Pelajaran Ekonomi SMA Ngeri 1 Sungai Ambawang. Jurnal Pendidikan Dan Pembelajaran Khatulistiwa, 5(11), 2-13.

\footnotetext{
Nana, S.2012. Penelitian dan Penilaian pendidikan. Bandung :Sinar Baru Algensindo
}

Novitasari, L., Agustina, P. A., Sukesti, R., Nazri, M. F., \& Handhika, J. (2017). Fisika, Etnosains, dan Kearifan Lokal dalam Pembelajaran Sains. Seminar Nasional Pendidikan Fisika III 2017, 8188.

Nur Laili,L., Munika, S., Sekar, A., Singgih, S. (2019). Pengembangan Puzzle Trigonometri untuk Meningkatkan Motivasi Belajar Matematika Siswa Sekolah Menengah Atas. Jurnal Komunikasi Pendidikan. 3 (2), 101-107. http://journal.univetbantara.ac.id/index.php /komdik/article/view/324

Karunia, A \& Muhsin.(2019).Pengaruh Minat Belajar, Motivasi Belajar, Lingkungan Keluarga, dan Lingkungan Sekolah Terhadap Kesulitan Belajar. (2019). Department of Economics Education, Faculty of Economics, Universitas Negeri Semarang, Vol 8 No 2 (2019): Economics Education Analysis Journal. https://journal.unnes.ac.id/sju/index.php/ee aj/article/view/31517

Rusli, A. (2011). Fisika Dasar dan Kesadaran Ilmiah: Suatu Studi-Analisis Kaitan Fisika dengan Dunia Digital. Research ReportEngineering Science, Query date: 202008-14 14:24:03. http://journal.unpar.ac.id/index.php/rekaya sa/article/download/65/54

Susanti, R. D. (2018). Strategi Guru Kelas Dalam Mengatasi Kesulitan Belajar Akademik Siswa Dalam Pembelajaran Di Sekolah Dasar. KONSELING EDUKASI "Journal of Guidance and Counseling, "2(1). https://doi.org/10.21043/konseling.v2i2.44 70

Sugiyono. (2014). Metode penelitian kuantitatif, Kualitatif dan $R \& D$.Bandung : Alfabeta. 